\title{
MERINTIS DESA HIJAU MANDIRI MELALUI PROGRAM KEBUN BIBIT MASYARAKAT DI DESA PANGGULO BARAT, KECAMATAN BOTUPINGGE KABUPATEN BONE BOLANGO, PROVINSI GORONTALO
}

\section{Passing The Mandiri Green Village Through Community Breeding Programs In Panggulo Barat Subdistrict Botupingge Bone Bolango District Gorontalo province}

\author{
Ika Okhtora Angelia \\ Staf Pengajar Program Studi Teknologi Hasil Pertanian Politeknik Gorontalo \\ J1. Muchlis Rahim Desa Panggulo, Kecamatan Botupingge, Bone Bolango, Gorontalo \\ Email : ikaokhtora@poligon.ac.id
}

\begin{abstract}
ABSTRAK
Desa Panggulo Barat merupakan desa lingkar kampus dan hanya berjarak +200 meter dari kampus Politeknik Gorontalo. Lokasi pemukiman warga di desa ini sebagian berada di tepi sungai Bone dan selebihnya di wilayah pegunungan yang tandus. Terdapat banyak lahan kosong di Desa Panggulo Barat yang belum dimanfaatkan, hal ini disebabkan karena kondisi tanah yang berkapur dan tandus serta kurangnya budaya menanam warga. Sebagian warga yang tinggal di tepian sungai Bone memiliki tanah yang cukup subur sehingga cocok untuk ditanami berbagai jenis tanaman hortikultura seperti cabai, tomat, tanaman hias daun dan tanaman biofarmaka. Namun masyarakat masih menggunakan benih yang ditanam berulang-ulang sehingga hasil panen tidak maksimal. Untuk itu diperlukan edukasi melalui upaya perbaikan perbanyakan tanaman yang dimulai dari teknik-teknik persemaian dan pemilihan bibit unggul yang bermutu sehingga memperoleh hasil panen yang baik serta mampu meningkatkan kesejahteraan dan gizi masyarakat yang berasal dari hasil panen dari pekarangan rumah. Program PHBD ini bertujuan untuk memfasilitasi kelompok masyarakat yang ingin mengembangkan pembibitan terutama di wilayah tempat tinggalnya. Metode pelaksanaan PHBD ini adalah melakukan pelatihan teknik persemaian, pemilihan bibit bermutu, pembuatan pupuk hayati dan kegiatan pemanfaatan lahan sempit dengan pembuatan instalasi vertikultur (urban farming). Hasil akhir yang telah didapatkan dari kegiatan PHBD ini adalah masyarakat menjadi terampil dalam melakukan kegiatan budidaya tanaman dan dapat melakukan sendiri di masing-masing rumah warga sehingga lingkungan menjadi lebih hijau dan meningkatkan perekonomian masyarakat melalui penjualan bibit tanaman.
\end{abstract}

Kata kunci : Desa Hijau, Kebun Bibit Masyarakat, Urban Farming

\begin{abstract}
Panggulo Barat Village is a village around the campus and only +200 meters from the Gorontalo Polytechnic campus. The location of residential areas in this village is partly on the banks of the Bone River and the rest in the barren mountainous regions. There is a lot of vacant land in the West Panggulo Village that has not been utilized; this is due to the condition of the calcareous and barren land and the lack of planting resident culture. Some residents who live on the banks of the river Bone have enough fertile land to be suitable for planting various types of horticultural plants such as chili, tomatoes, ornamental leaf plants, and biopharma plants. However, the community still uses seeds that are planted repeatedly so the yield is not optimal. For this reason, education is needed through efforts to improve plant propagation starting from nursery techniques and selection of superior quality seeds so that they get good harvests and can improve the welfare and nutrition of the people from the crops of the home garden. The PHBD program aims to facilitate community groups who want to develop nurseries, especially in the area where they live. The method of implementing this PHBD is conducting nursery technical training, selecting quality seeds, making biological fertilizers, and narrow land use activities by making verticultural installations (urban farming). The result that has been obtained from this PHBD activity is that the community becomes skilled in conducting plant cultivation activities and can do it themselves in each of the residents' homes so that the environment becomes greener and improves the economy of the community through the sale of plant seeds.
\end{abstract}

Keywords: Green Village, Community Seed Garden, Urban Farming 


\section{PENDAHULUAN}

Desa Panggulo Barat memiliki lokasi geografis yang cukup strategis karena merupakan kabupaten terdekat dengan ibu kota Provinsi Gorontalo (berada di Kabupaten Bone Bolango yang hanya berjarak $2 \mathrm{~km}$ dari ibu kota Gorontalo). Topografinya didominasi dengan wilayah pegunungan dan sebagian lainnya berada di tepian Sungai Bone. Banyak terdapat lahan kosong di Desa Panggulo Barat yang belum dimanfaatkan. Hal ini disebabkan karena kondisi tanah yang berkapur dan tandus serta kurangnya budaya menanam warga. Sebagian warga yang tinggal di tepian sungai Bone memiliki tanah yang cukup subur sehingga cocok untuk ditanami berbagai jenis tanaman hortikultura seperti cabai, tomat, tanaman hias daun dan tanaman biofarmaka. Namun masyarakat masih menggunakan benih yang ditanam berulang-ulang sehingga hasil panen tidak maksimal. Untuk itu diperlukan edukasi melalui upaya perbaikan perbanyakan tanaman yang dimulai dari teknik-teknik persemaian dan pemilihan bibit unggul yang bermutu sehingga memperoleh hasil panen yang baik serta mampu meningkatkan kesejahteraan dan gizi masyarakat dari hasil panen dari pekarangan rumah.

Berangkat dari kondisi tersebut, perlu digalakkan budaya menanam melalui program penghijauan yang bertujuan untuk meningkatkan keragaman hayati dalam bentuk kegiatan pelatihan persemaian bibit dan pemeliharaan tanaman yang pada akhirnya merangsang kemandirian masyarakat dalam menyediakan bibit bermutu melalui program kebun bibit masyarakat. Kebun Bibit Masyarakat (KBR) merupakan program yang pernah digalakkan oleh pemerintah dalam hal pembibitan dan penyediaan bibit masyarakat. Salah satu tujuannya adalah mencegah, menanggulangi bencana, penyedia Oksigen $(\mathrm{O} 2)$, penyerap racun dari udara yang terkontaminasi dan secara tidak langsung akan berpengaruh positif terhadap lingkungan sekitar. Program Kebun Bibit Masyarakat ini bertujuan untuk memfasilitasi kelompok masyarakat yang ingin mengembangkan pembibitan dan meningkatkan perekonomian warga melalui hasil panen dari pekarangan. Selain itu dilakukan juga program vertikultur yaitu teknik penanaman di lahan sempit/pekarangan dimana kita dapat memanfaatkan talang air sebagai tempat bercocok tanam sehingga bagi masyarakat yang memiliki lahan pekarangan yang sempit tetap dapat menanam tanaman.

\section{GAMBARAN UMUM MASYARAKAT SASARAN}

Daerah yang menjadi sasaran adalah warga masyarakat yang memiliki lahan yang belum dimanfaatkan secara produktif di Desa

Panggulo Barat, Kecamatan Botupingge,

Kabupaten Bone Bolango, Provinsi Gorontalo. Desa Panggulo Barat terletak di Jalan Muchlis Rahim yang merupakan jalan utama di wilayah Kecamatan Botupingge. Lokasinya strategis karena berdekatan dengan kampus Politeknik Gorontalo, SMK Negeri Model Gorontalo, dan beberapa perkantoran diantaranya Polsek Botupingge, Kantor Kecamatan Botupingge, Kantor Dinas Pendidikan Kecamatan Botupingge, Balai Nikah Botupingge dan Kantor BP3K Kecamatan Botupingge (Balai Pertanian, Perikananan, Peternakan dan Kehutanan). Desa Panggulo Barat hanya berjarak kurang lebih $200 \mathrm{~m}$ dari kampus Politeknik Gorontalo. Dengan adanya pemilihan lokasi yang mudah dijangkau, diharapkan dapat memudahkan perguruan tinggi dalam proses pelaksanaan program serta saat pasca pelaksanaan program bina desa ini.

Lokasi dan agroklimat Desa Panggulo Barat yang sebagian besar kurang subur dan berada di dataran tinggi menyebabkan sebagian besar penduduknya menggantungkan hidup sebagai petani. Namun beberapa penduduk yang tinggal di tepi sungai bone menggantungkan hidupnya sebagai petani. Petani biasanya menanam cabai dan tomat dengan menggunakan bibit yang berasal dari biji 
yang disemaikan sendiri. Jika dilihat dari fisiologi tanamannya, hasil panen yang berasal dari biji tanaman yang telah disemai berulang-ulang hasilnya akan menurun tidak sebaik tanaman awalnya (F1). Oleh karena itu diperlukan suatu edukasi dan upaya perbaikan teknik-teknik perbanyakan tanaman yang dimulai dari pemilihan bibit unggul yang bermutu sehingga hasil panen baik kualitas maupun kualitasnya akan terus meningkat. Selain itu diharapkan setelah diberikan pelatihan mengenai teknik-teknik perbanyakan tanaman, masyarakat Desa Panggulo Barat dapat memanfaatkan lahan pekarangan yang tidak produktif untuk dijadikan kebun bibit masyarakat.

Desa Panggulo Barat merupakan desa berpenduduk terbanyak di Kecamatan Botupingge. Mata pencaharian penduduk Desa Panggulo Barat adalah buruh tani dan buruh bangunan, serta mayoritas ibu-ibu rumah tangga di desa ini tidak bekerja. Padahal jika hanya mengandalkan nafkah dari hasil pertanian dan upah sebagai buruh bangunan yang hasilnya tidak menentu tidak akan cukup untuk memenuhi kebutuhan hidup keluarga sehari-hari. Pihak-pihak yang akan menjadi mitra dalam kegiatan ini antara lain adalah Pemerintah Desa Panggulo Barat dan Politeknik Gorontalo. Peran mitra dalam pelaksanaan program dan pasca program, diantaranya :

1. Pemerintah Desa Panggulo Barat akan membantu mencarikan kelompok sasaran dan menyediakan lahan yang tidak dimanfaatkan milik masyarakat yang akan digunakan untuk pelaksaan program. Selain itu Pemerintah Desa berupaya untuk menyediakan tempat/balai pertemuan sebagai lokasi pelatihan dan praktek. Pasca kegiatan diharapkan ada kegiatan lanjutan yang mungkin belum sempat terlaksana atau gagasan baru yang muncul saat berlangsungnya program.
2. Politeknik Gorontalo khususnya mahasiswa pengusul proposal akan berperan aktif sebagai pihak penyelenggara baik dalam menyampaikan materi pelatihan dan melakukan kegiatan praktek di lapangan. Dosen pembimbing dapat berperan sebagai narasumber dan memberikan pengarahan serta masukanm agar semua program yang telah direncanakan dapat berjalan dengan lancar. Kampus memprioritaskan kegiatan penelitian dan pengabdian di desa binaan.

\section{Permasalahan Mitra}

Identifikasi masalah dilakukan guna untuk mendapatkan informasi tentang kondisi lingkungan di masyarakat Desa Panggulo Barat melalui wawancara dan melihat kondisi nyata di lapangan. Jumlah peserta yang diikutsertakan pada program ini berjumlah 20 orang yang terdiri dari para ibu rumah tangga dan pemuda pengangguran.

Suasana pedesaan yang terbilang cukup gersang dan tandus serta jarang ditanami menjadi salah satu gagasan untuk menghijaukan desa ini sekaligus memberdayakan masyarakatnya untuk mandiri dan berwirausaha dalam bidang pertanian. Masyarakat sangat membutuhkan benih bermutu dan bebas penyakit yang akan ditanam sebagai $\mathrm{F}$ 1. Oleh karena itu diperlukan program penghijauan sekaligus peningkatkan pendapatan sekaligus menumbuhkan jiwajiwa enterpreneur melalui kebun bibit masyarakat. Dalam program ini akan disiapkan berbagai macam benih dan bibit serta peralatan penunjang kegiatan.

Tahapan kegiatan dalam menyelesaikan permasalahan sekaligus pencapaian tujuan program adalah sebagai berikut : 
- Observasi dan sosialisasi

- Penyuluhan dan Pelatihan Teknis

- Diskusi Interaktif

- Tinjauan dan Evaluasi Kegiatan

- Promosi dan Sosialisai Hasil Kegiatan

Metode yang akan digunakan dalam pelaksanaan program ini adalah metode pembelajaran melalui audio visual disertai praktek secara langsung. Cara yang digunakan untuk mencapai keberhasilan program diantaranya adalah :

1. Bersikap aktif dan komunikatif dalam mengajak masyarakat untuk mendukung dan berpartisipasi dalam setiap tahapan program yang direncanakan

2. Secara terus menerus melakukan pendekatan kepada masyarakat dalam memberikan informasi mengenai arti pentingnya desa binaan dan Posdaya baik bagi masyarakat desa sasaran ataupun kampus karena dapat membuka akses kegiatan penelitian dan pengabdian masyarakat sehingga ada transfer ilmu pengetahuan dan hubungan timbal balik antara kampus dengan desa binaan pasca program.

3. Menjalin kemitraan yang baik dan melakukan konsultasi dengan stakeholder di Desa Panggulo Barat diantaranya Kantor BP3K Kecamatan

Botupingge serta mengikutsertakan mereka dalam program yang diadakan. Diharapkan outputnya akan muncul ide dan gagasan baru untuk merencanakan kegiatan baru pasca program.

\section{METODE PELAKSANAAN}

Pelaksanaan PHBD dimulai pada pertengahan bulan Juli 2016 sampai dengan awal Desember 2016, bertempat di Desa Panggulo Barat, Kecamatan Botupingge, Kabupaten Bone Bolango, Provinsi Gorontalo. Program-program yang telah dilakukan adalah sebagai berikut :
1. Pembersihan Lahan Tanam: hal ini bertujuan untuk membersihkan lahan dari gulma dan patogen penyebab hama dan penyakit tanaman

2. Prinsip Dasar Persemaian: dilakukan dengan menyemai berbagai jenis benih tanaman pada traysemai dan memindahkannya kedalam polybag setelah 1-2 minggu

3. Pembuatan Vertikultur (Model Urban Farming): vertikultur adalah teknik penanaman di lahan sempit/pekarangan dimana kita dapat memanfaatkan

barang bekas sebagai tempat tanam misalnya penggunaan bambu dan talang air.

4. Persilangan Tanaman: setelah tanaman berbunga maka dimulailah kegiatan persilangan tanaman yaitu dengan membantu menyerbukkan benang sari ke kepala putik tanaman seperti cabai dan tomat. Selain itu dilakukan juga kegiatan perbanyakan tanam dengan cara pemisahan anakan.

5 Pembuatan pupuk hayati dengan menggunakan kompos Trichoderma $\mathrm{sp}$

6. Perawatan Tanaman : menyiangi rumput dan melakukan sulam tanaman (selama 3 bulan)

\section{EVALUASI DAN KEBERLANJUTAN}

Pada awal sosialisasi program PHBD ini masih terlihat adanya keengganan warga mengikuti rangkaian kegiatan PHBD walaupun pada akhirnya setelah program ini berlangsung antusiasme warga yang mengikuti sangatlah besar terbukti peserta selalu hadir disetiap acara dilangsungkan dan banyaknya pertanyaan peserta yang menunjukkan rasa ingin tahu mereka dalam kegiatan budidaya tanaman. Evaluasi pasca kegiatan ini adalah masih kurangnya kesadaran warga dalam merawat tanaman padahal jadwal perawatan sudah diberikan.

Harapannya kedepannya ada keberlanjutan pasca program ini yaitu hasil 
panen/bibit yang ada di kebun bibit masyarakat dibeli oleh warga sekitar dengan menggunakan sistem jual beli tanpa menggunakan uang melainkan menukarnya dengan sampah, sehingga selain lingkungan menjadi bersih juga bebas sampah (baik sampah hayati maupun sampah plastik).

Hal ini sudah hampir dirintis namun masih terkendala dengan sosialisasi kepada warga, lokasi penyimpanan sampah plastik juga alat pengolahan sampah plastik menjadi bubur plastik yang kemudian diolah menjadi barang yang terbuat plastik. Sedangkan sampah hayati yang terkumpul akan dijadikan kompos yang nantinya bisa digunakan untuk pemupukan sehingga bias menekan biaya perawatan tanaman.

\section{KESIMPULAN DAN SARAN}

Kegiatan PHBD ini berjalan lancar. Indikator keberhasilan kegiatan ini diantaranya :

1. Antusiasme masyarakat yang tercermin dari partisipasi warga dalam bentuk kehadiran disetiap tahapan kegiatan yang dilaksanakan. Program diikuti oleh ibu rumah tangga dan pemuda desa yang mencapai $90 \%$ dari seluruh undangan.

2. Tersusunnya panduan tata cara budidaya tanaman hortikultura

3. Secara fisik, Desa Panggulo Barat yang dahulunya gersang dan tandus kini berubah menjadi kawasan hijau dan asri dengan banyaknya masyarakat yang mulai menanami lahan dan kebunnya dengan berbagai macam tanaman hortikultura.

4. Desa Panggulo Barat menjadi daerah cikal bakal POSDAYA kampus Politeknik Gorontalo yang akan membuka akses kegiatan penelitian dan pengabdian masyarakat untuk tahun kedepannya sehingga menimbulkan hubungan timbal balik dan transfer ilmu pengetahuan antara kampus dengan desa binaan.
5. Terjalin kemitraan yang baik antara kampus Politeknik Gorontalo dan Pemerintah Desa Panggulo Barat sehingga di tahun-tahun berikutnya muncul ide untuk bersama-sama merencanakan dan melaksanakan program pasca kegiatan

Saran setelah kegiatan PHBD ini dilaksanakan, masyarakat yang telah diberi pengajaran berupa teknik-teknik budidaya tanaman dapat membudidayakan tanaman di lahan pekarangannya sendiri. Kegiatan ini akan menghasilkan hasil yang optimal jika dibentuk kelompok tani sehingga bisa memangkas kebutuhan dana dan lokasi kebun bibit masyarakat menjadi lebih luas sehingga menghasilkan hasil panen yang beragam.

\section{DAFTAR PUSTAKA}

Cahya, D.L. 2014. Kajian Peran Pertanian Perkotaan Dalam Pembangunan Perkotaan Berkelanjutan (Studi Kasus : Pertanian Tanaman Obat Keluarga di Kelurahan Slipi, Jakarta Barat). Forum Ilmiah Volume 11 Nomor 3. Hal 324333

Ismail, $\mathrm{N}$ dan Andi, T. 2011. Potensi Agens Hayati Trichoderma sp sebagai Pengendali Hayati. BPTP Sulawesi Utara

Nur'aini, A. D dan J. Krisdianto. 2016. Urban Farming dalam Kampung Vertikal sebagai Upaya Efisiensi Ketrerbatasan Lahan. Jurnal Sains dan Seni Pormits Vol. 6 No. 2(2337-3520). Departemen Aristektur Fakultas Teknik Sipil dan Perencanaan. Institut Teknologi Sepeuluh Nopember (ITS). 